\title{
Research on Runoff Pollution Characteristics and Countermeasures at Sensitive Highway Sites
}

\author{
Yanhua Wang, Chanjuan Gao, Shengke Yang* Guobin Ji, Xiuhua Liu \\ Chang'an University, School of Environmental Science and Engineering, Chang'an University, \\ Yanta Road 126, Yanta District, 710064 Xi'an, China
}

Received: 8 September 2015

Accepted: 3 January 2016

\begin{abstract}
Pollution and control on highway surface runoff have become a serious problem in highway environmental protection. Constructing a highway in a water conservation district could bring benefits as well as a variety of environmental pollution and potential damage. Based on water conservation district sensitivity and highway runoff characteristics, the current paper analyzes the impact of highway runoff on water quality in the water source protection area. It hasn't yet had a good and mature process with respect to the drainage of the drinking water source reserves of domestic highways. It was designed as a concentrated drainage treatment system to process the drainage of sensitive sections as outlined in this paper. Highway surface runoff characteristics were studied by monitoring, investigating, sampling, and analyzing the Renhuai-toChishui highway $(\mathrm{RCH})$, and then the concentrated drainage treatment system was designed, and the water is collected piecewise along the route. The processing system can not only effectively deal with road surface runoff of the water source protection area, but also to cope with risk. Combined with the actual situation of water source conservation areas around $\mathrm{RCH}$, we have carried out a detailed demonstration of the drainage system in order to mollify the contradiction between the water resource protection area and development of traffic in the water reserves. The results showed that the processing rates - as high as $83.17-93.77 \%$ - and the concentrated drainage treatment system could guarantee effluents meeting discharge standards. This study demonstrates the effectiveness of the concentrated drainage treatment system in RCH and establishes an advanced technology for highway surface runoff control.
\end{abstract}

Keywords: highway runoff, characteristics of pollutants, water source protection area, control measures, correlation analysis

\section{Introduction}

With the rapid development of road construction, highway runoff pollution prevention and control has

*e-mail: ysk110@126.com become one of the important problems of highway environmental protection. Highway runoff pollution is the main component of surface runoff pollution, which is the second worst area-source of pollution next to agricultural pollution. Besides heavy metals and hydrocarbon, road rainwater contains plenty of vehicle exhaust pollutants by natural sedimentation or rainwater leaching, which 
causes water pollution [1]. Some studies have shown that when rural highway traffic reaches 30,000 vehicles per day, runoff can destroy the function of nearby rivers [2]. Hence, developing research on road surface runoff pollution has an important practical significance and guiding significance. This paper investigated the features of highway runoff pollutants, emission control rules, and control measures.

Since the 1970s many western countries have carried out research on runoff pollution and its impact factors. Stotz et al. [3] first studied 145 rounds of rainfall runoff in West Germany from 1978 to 1981, the results showing that runoff pollutants included heavy metals, mineral oil, chloride, COD (chemical oxygen demand), SS (suspended solids), BOD (biological oxygen demand), and PAHs (polycyclic aromatic hydrocarbons), etc. In 1988, Barrett et al. [4] researched runoff in Texas. From 1997 to 2001, Kayhanian et al. [5] studied water quality and related research of runoff of California highways. These research results showed that the main pollutants in road runoff were $\mathrm{SS}$, COD, BOD, heavy metals (such as $\mathrm{Pt}, \mathrm{Cr}, \mathrm{Cu}$, and Ni), PAHs, oil, and grease, etc., some also contained deicing salt. Compared to other developed countries, China started road runoff treatment technology late. Zhao et al. sampled, monitored, and analyzed the deck runoff of the Xi'an-to-Lintong highway in 2001 [1]. The results showed that the main pollutants in runoff were SS and $\mathrm{COD}$, and SS concentration was in the range of $126 \mathrm{mg} / \mathrm{L}$ to $813 \mathrm{mg} / \mathrm{L}$ and the average concentration was $347 \mathrm{mg} / \mathrm{L}$, which is far beyond the China I-class criteria specified in the Integrated Wastewater Discharge Standard (GB89781996). Ren [6] carried out runoff water quality monitoring up to two years from 2003 to 2005 on the Xi'an-Yan'an highway, the result showing that the primary pollutant was SS and secondary was COD, and the contents of $\mathrm{Pb}$ (lead), zinc, and other heavy metal were low. Deng et al. [7] studied the Zaozhuang-Hengshui highway in 2007 and the results showed the main pollutant in runoff was SS and the concentrations of the water pollution in the road on both sides decreased with the increase of the distance of the road. Li et al. monitored surface runoff of the Nanjing airport highway, the results showing that the median concentrations of $\mathrm{SS}, \mathrm{COD}, \mathrm{BOD}_{5}, \mathrm{NH}_{3}-\mathrm{N}$ (ammoniae nitrogen), TN (total nitrogen), and TP (total phosphorus) were 26.127, 19.50, 1.59, 4.44, and $0.28 \mathrm{mg} / \mathrm{L}$, respectively, and the research suggested that $\mathrm{SS}, \mathrm{COD}$, and TP was affected by rainfall intensity, while $\mathrm{NH}_{3}-\mathrm{N}$, and $\mathrm{TN}$ were mainly affected by precipitation [8$10]$.

So far, there are a lot of theories about the runoff process, but little practical application. Zhong et al. [11] did some experimental research on the process effect of Chongqing-Zhanjiang highway runoff in 2007, which demonstrates that a constructed wetland has great significance in practice. Mao et al. [12] analyzed the outflow rule of Chongqing-Wuhan highway runoff in 2010, and the results were as follows:

1) Most of the pollutant concentrations were higher than the environmental quality standard of surface water
(GB3838-2002) V grade and the secondary standard in integrated wastewater discharge standard (GB89781996) of China.

2) The concentrations of SS, COD, TN, and TP were high and their contributions to pollution were much more, which are the main pollutants.

3) A good linear relationship between $\mathrm{COD}, \mathrm{BOD}_{5}, \mathrm{~Pb}$, $\mathrm{Zn}$ (zinc), $\mathrm{Cu}$, and $\mathrm{SS}$ existed, and its regression effect was good.

The results point to a scientific basis and methods for runoff pollution control management. In addition, many scholars have carried out a lot of research on highways in sensitive water areas. $\mathrm{Li}$ et al. studied the pollution characteristics of pavement and bridge deck runoff on the Beijing-Chengde highway in 2010 [13]. The event mean concentrations of $\mathrm{COD}, \mathrm{SS}, \mathrm{TP}, \mathrm{NH}_{3}-\mathrm{N}$, and petroleum exceeded the corresponding standards, and heavy metal pollution was slight. The Guangzhou belt highway stretched across the Beijing River and other secondary sources of drinking water. Lu et al. [14] put forward an artificial wetland to treat bridge deck runoff, and the relevant technological process was designed in 2008 . Liu et al. [15] recommended processing road surface runoff pollution in water conservation treatment using a biological filter. Ye et al. [16] monitored the rainfall runoff water quality of toll gates, service areas, and gas stations of Changtanxi highway in Hunan province in 2013. They analyzed the pollution characteristics of runoff and discussed the early scouring effect of the pollutants and the correlation between the pollution factors. Chen et al. [17] have studied the seasonal variation characteristics and the cause analysis of road runoff pollution using the one-way ANOVA method in 2014.

Based on previous studies, it was found that it is impossible to effectively dispose of runoff and address emergency dangerous chemical leaks using only one measure. Our paper has taken sensitive drinking water reserves of $\mathrm{RCH}$ as an example. We have monitored the water quality of drinking water reserves and the runoff in $\mathrm{RCH}$, evaluated the water quality of water source protection areas, and analyzed the event mean concentration and the correlation of surface runoff contamination. We put forward a feasible countermeasure in connection with collecting and processing the runoff in the highway water reserve's sensitive sections, and the feasibility is carried on, which provides relevant research materials and the basis for road surface runoff pollution control of different locations along the highway.

\section{Research Methods}

\section{Regional Overview}

The research object is $\mathrm{RCH}$, which opened to traffic in October 2013. It is two-way and four-lane, and the path length is $156.576 \mathrm{Km}$. It goes through three drinkingwater source protection areas at $\mathrm{K} 10+950--\mathrm{K} 18+750$ sections, and the specific engineering behavior is shown 
Table 1. Engineering behavior summary of RCH in the drinking water source protection area.

\begin{tabular}{|c|c|c|c|c|}
\hline Stake & $\begin{array}{l}\text { Name of sensitive } \\
\text { water body }\end{array}$ & $\begin{array}{l}\text { Water body } \\
\text { function }\end{array}$ & Function & Relationship with RCH \\
\hline $\mathrm{K} 10+950-\mathrm{K} 11+650$ & Maobagou reservoir & $\begin{array}{l}\text { Renhuai City } \\
\text { drinking water, } \\
\text { irrigation }\end{array}$ & $\begin{array}{l}\text { Centralized } \\
\text { drinking } \\
\text { water source } \\
\text { areas }\end{array}$ & $\begin{array}{l}\text { The route goes through the secondary water } \\
\text { reserves of MaoBagou reservoir at K10+950 } \\
\text { - K11 + 650, and the closest distance is } 178 \mathrm{~m} \text {, } \\
\text { and the route locates downstream of the dam. }\end{array}$ \\
\hline $\begin{array}{c}\mathrm{K} 13+060-\mathrm{K} 14+150 \& \\
\mathrm{~K} 15+700-\mathrm{K} 17+400\end{array}$ & Liushayan reservoir & $\begin{array}{l}\text { Renhuai City } \\
\text { drinking water, } \\
\text { irrigation }\end{array}$ & $\begin{array}{l}\text { Centralized } \\
\text { drinking } \\
\text { water source } \\
\quad \text { areas }\end{array}$ & $\begin{array}{l}\text { The route goes through the secondary water } \\
\text { reserves of LiuShayan reservoir at K13 + } 060- \\
\mathrm{K} 14+150 \& \mathrm{~K} 15+700-\mathrm{K} 17+400 \text {, and the } \\
\text { closest distance is } 145 \mathrm{~m} \text {, and the route locates } \\
\text { downstream of the dam. }\end{array}$ \\
\hline $\mathrm{K} 17+650-\mathrm{K} 18+750$ & Banqiao reservoir & $\begin{array}{l}\text { Renhuai City } \\
\text { drinking water, } \\
\text { irrigation }\end{array}$ & $\begin{array}{l}\text { Centralized } \\
\text { drinking } \\
\text { water source } \\
\text { areas }\end{array}$ & $\begin{array}{l}\text { The route goes through the secondary water } \\
\text { reserves of MaoBagou reservoir at K17 }+650- \\
\mathrm{K} 18+750 \text {, and the closest distance is } 8 \mathrm{~m} \text {, and } \\
\text { the route locates downstream of the dam. }\end{array}$ \\
\hline
\end{tabular}

in Table 1 and Fig. 1. This paper analyzes the three drinking water source protection areas and the runoff water of $\mathrm{RCH}$, and the specific sampling points are shown in Table 2.

\section{Sampling}

Sampling in road surface runoff is manual sampling using clean polyethylene bottles for the entire rainfall events. Before the formation of runoff, we sampled every five minutes; after the formation of runoff for 30 to 60 min, it was sampled every $15 \mathrm{~min}$; in the rest of the rainfall process, it was sampled every $30 \mathrm{~min}$ until the end of the precipitation. The amount of rainfall should be recorded in the whole study. According to the rainfall characteristics of the Renhuai area, we carried out a number of samples in $\mathrm{RCH}$ runoff from June to September in 2014. In this study, we selected a typical rainfall runoff to analyze its characteristics. The status of rain and sampling were shown in Table 3.

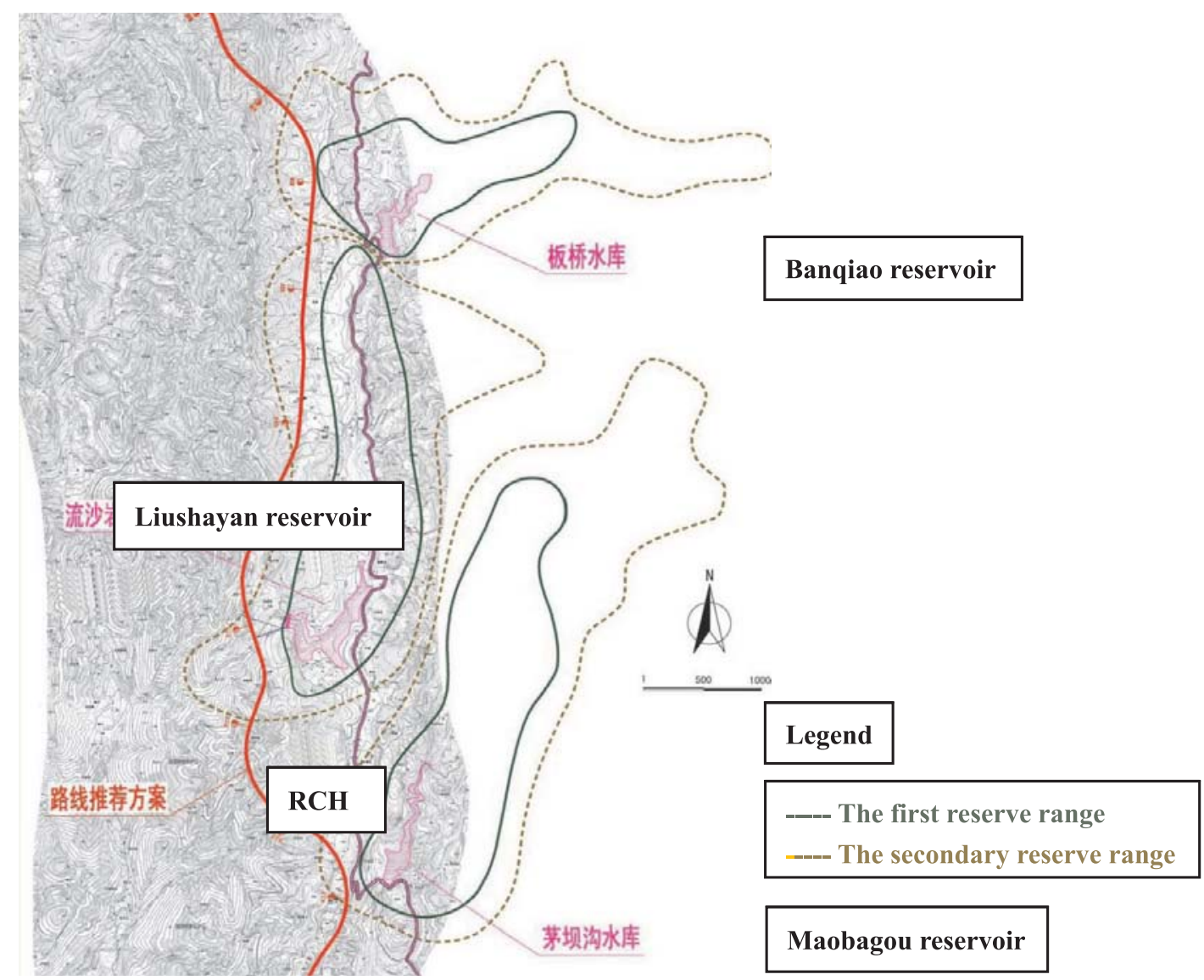

Fig. 1. The position diagram of $\mathrm{RCH}$ and three drinking water sources reserve. 
Table 2. Reservoir water environment status monitoring table.

\begin{tabular}{|c|c|c|}
\hline The name of the water areas & Sampling sites & Monitoring indexes \\
\hline \multirow{3}{*}{ Maobagou Reservoir } & the most distant distance route & \multirow{9}{*}{$\begin{array}{c}\mathrm{COD}, \mathrm{pH}, \mathrm{BOD}_{5}, \mathrm{NH}_{3}-\mathrm{N}, \\
\text { petroleum, TP, heavy metal, etc. }\end{array}$} \\
\hline & downstream of the reservoir & \\
\hline & reservoir upstream, slope into the reservoir & \\
\hline \multirow{3}{*}{ Liushayan Reservoir } & the most distant distance route & \\
\hline & downstream of the reservoir & \\
\hline & reservoir upstream, the recent distance routes & \\
\hline \multirow{3}{*}{ Banqiao Reservoir } & the most distant distance route & \\
\hline & downstream of the reservoir & \\
\hline & reservoir upstream, the recent distance routes & \\
\hline $\mathrm{RCH}$ & road runoff & \\
\hline
\end{tabular}

Table 3. Characteristics of a rainfall event.

\begin{tabular}{|c|c|c|c|c|}
\hline Date & $\begin{array}{c}\text { Rainfall } \\
(\mathrm{mm})\end{array}$ & $\begin{array}{c}\text { Duration } \\
\text { of rainfall } \\
(\mathrm{min})\end{array}$ & $\begin{array}{c}\text { Duration } \\
\text { of runoff } \\
(\mathrm{min})\end{array}$ & $\begin{array}{c}\text { Drying } \\
\text { period } \\
\text { before rain } \\
(\mathrm{h})\end{array}$ \\
\hline $2014-07-11$ & 7.2 & 85 & 92 & 156 \\
\hline
\end{tabular}

\section{Sample Analysis [18]}

Reservoir water samples and runoff samples were promptly sent to the laboratory for water quality analysis after sampling, and the analysis indexes included $\mathrm{pH}$, $\mathrm{SS}, \mathrm{COD}, \mathrm{BOD}_{5}, \mathrm{TN}, \mathrm{TP}, \mathrm{Cu}, \mathrm{Zn}, \mathrm{Pb}, \mathrm{Cd}$, etc., and the monitoring methods are shown in Table 4.

Table 4. Monitoring indicators and test methods.

\begin{tabular}{|c|c|c|}
\hline project & $\begin{array}{c}\text { Determination } \\
\text { method }\end{array}$ & Methods source \\
\hline $\mathrm{SS}$ & Gravimetric method & $\mathrm{GB} / \mathrm{T} 11901-89$ \\
\hline $\mathrm{NH}_{3}-\mathrm{N}$ & $\begin{array}{c}\text { Nessler's reagent } \\
\text { colorimetric }\end{array}$ & $\mathrm{GB} / \mathrm{T} 7478-87$ \\
\hline $\mathrm{COD}$ & $\begin{array}{c}\text { Potassium } \\
\text { dichromate }\end{array}$ & $\mathrm{GB} / \mathrm{T} 11914-89$ \\
\hline $\mathrm{BOD}_{5}$ & $\begin{array}{c}\text { Dilution and seeding } \\
\text { method }\end{array}$ & $\mathrm{GB} / \mathrm{T} 7488-87$ \\
\hline $\mathrm{pH}$ & $\begin{array}{c}\text { Glass electrode } \\
\text { method }\end{array}$ & $\mathrm{GB} / \mathrm{T} 6920-86$ \\
\hline petroleum & $\begin{array}{c}\text { Infrared } \\
\text { spectrophotometry }\end{array}$ & $\mathrm{GB} / \mathrm{T} 16488-1996$ \\
\hline $\mathrm{Pb}$ & $\begin{array}{c}\text { Atomic absorption } \\
\text { spectrophotometry }\end{array}$ & $\mathrm{GB} / \mathrm{T} 7475-87$ \\
\hline $\mathrm{TP}$ & $\begin{array}{c}\text { Molybdate } \\
\text { spectrophotometry }\end{array}$ & $\mathrm{GB} / \mathrm{T} 11893-1989$ \\
\hline Fecal coliform & $\begin{array}{c}\text { Multi-tube } \\
\text { fermentation }\end{array}$ & $\mathrm{HJ} / \mathrm{T} 347-2007$ \\
\hline
\end{tabular}

\section{Results and Discussion}

\section{Situation of Water Quality Monitored in the Reservoir}

From Table 5, the single factor index of each monitoring factor in each monitoring section is less than or equal to one, and the water quality can meet the surface water environment quality class II standard (GB38382002). This showed that the water quality of Maobagou, Liushayan, and Banqiao reservoirs was good.

\section{Runoff Water Quality Analysis}

As typical sewage water quality index of China, SS is $220 \mathrm{mg} / \mathrm{L}, \mathrm{BOD}_{5}$ is $200 \mathrm{mg} / \mathrm{L}, \mathrm{COD}$ is $400 \mathrm{mg} / \mathrm{L}$. It showed that the concentration of COD was similar with typical sewage in RCH runoff, while the concentration of SS was higher than the domestic sewage, up to 4 times (Table 6). The concentration ratio of BOD5 and COD was 0.19, which is far less than the typical domestic sewage's ratio (about 0.45 ). Combining with biodegradability evaluation, it was betrayed that the biodegradability of runoff in $\mathrm{RCH}$ was poor, and it should not apply conventional biological treatment method.

\section{Regression Analysis of Pollution Indicators}

Regression analysis was made to the measured $\mathrm{RCH}$ runoff, and the results showed that there were good linear relationships between SS and each of $\mathrm{COD}, \mathrm{BOD}_{5}, \mathrm{~Pb}$, $\mathrm{Zn}, \mathrm{TP}$, and $\mathrm{NH}_{3}-\mathrm{N}$, as well as between $\mathrm{Zn}$ and $\mathrm{Pb}$. The correlation between each index is shown in Table 7. In the research of highway runoff between $\mathrm{Zn}$ and $\mathrm{Pb}$ pollution, we used formula (1) to make a regression analysis between the other pollutants and SS:

$$
\mathrm{Y}=\alpha+\beta \mathrm{x}
$$

...where $\mathrm{Y}$ is the concentration of the other pollution 
Table 5. Current water environment monitoring results.

\begin{tabular}{|c|c|c|c|c|c|}
\hline Monitoring area & Evaluation factor & $\begin{array}{l}\text { Monitoring average results } \\
(\mathrm{mg} / \mathrm{L})\end{array}$ & $\begin{array}{l}\text { Evaluation Criteria } \\
\qquad(\mathrm{mg} / \mathrm{L})\end{array}$ & $\begin{array}{l}\text { Single factor } \\
\text { index }\end{array}$ & Status \\
\hline \multirow[t]{9}{*}{ Maobagou reservoir } & SS & 3.67 & $25^{*}$ & 0.15 & - \\
\hline & $\mathrm{pH}$ & 8.17 & $6-9$ & 0.60 & - \\
\hline & $\mathrm{NH}_{3}-\mathrm{N}$ & 0.11 & 0.5 & 0.24 & - \\
\hline & COD & 6 & 15 & 0.40 & - \\
\hline & $\mathrm{BOD}_{5}$ & 2 & 3 & 0.67 & - \\
\hline & petroleum & $0.05 \mathrm{~L}$ & 0.05 & $<1.00$ & - \\
\hline & $\mathrm{TP}$ & 0.01 & 0.025 & 0.40 & - \\
\hline & Fecal coliform & 460 & 2000 & 0.25 & - \\
\hline & $\mathrm{Pb}$ & 0.035 & 0.01 & 0.35 & - \\
\hline \multirow[t]{9}{*}{ Liushayan reservoir } & $\mathrm{SS}$ & 3.89 & $25 *$ & 0.16 & - \\
\hline & $\mathrm{pH}$ & 8.22 & $6-9$ & 0.62 & - \\
\hline & $\mathrm{NH}_{3}-\mathrm{N}$ & 0.25 & 0.5 & 0.54 & - \\
\hline & COD & 10 & 15 & 0.73 & - \\
\hline & $\mathrm{BOD}_{5}$ & 3 & 3 & 1 & - \\
\hline & petroleum & $0.05 \mathrm{~L}$ & 0.05 & $<1.00$ & - \\
\hline & $\mathrm{TP}$ & 0.02 & 0.025 & 0.80 & - \\
\hline & Fecal coliform & 607 & 2000 & 0.35 & - \\
\hline & $\mathrm{Pb}$ & 0.028 & 0.01 & 0.28 & - \\
\hline \multirow[t]{9}{*}{ Banqiao reservoir } & $\mathrm{SS}$ & 3.03 & $25 *$ & 0.12 & - \\
\hline & $\mathrm{pH}$ & 8.16 & $6-9$ & 0.59 & - \\
\hline & $\mathrm{NH}_{3}-\mathrm{N}$ & 0.11 & 0.5 & 0.22 & - \\
\hline & COD & 6 & 15 & 0.47 & - \\
\hline & $\mathrm{BOD}_{5}$ & 2 & 3 & 0.67 & - \\
\hline & petroleum & $0.05 \mathrm{~L}$ & 0.05 & $<1.00$ & - \\
\hline & $\mathrm{TP}$ & 0.01 & 0.025 & 0.40 & - \\
\hline & Fecal coliform & 410 & 2000 & 0.23 & - \\
\hline & $\mathrm{Pb}$ & 0.024 & 0.01 & 0.24 & - \\
\hline
\end{tabular}

Notes: with «*» for «quality standards for surface water resources» (SL63-94) II level standard; in «Status» column, «-» indicates the within the standard limits, «+» indicates beyond the limits.

indicators $(\mathrm{mg} / \mathrm{L}), \mathrm{x}$ is the concentration of SS $(\mathrm{mg} / \mathrm{L})$, and $\alpha$ and $\beta$ are regression parameters.

As inferred from Table 7, there were good linear relationships between each runoff water quality indicator and SS. The runoff water quality indicators included COD, $\mathrm{BOD}_{5}, \mathrm{~Pb}, \mathrm{Zn}, \mathrm{TP}$, and $\mathrm{NH}_{3}-\mathrm{N}$. In addition, it also showed good linear relationships between $\mathrm{Zn}$ and $\mathrm{Pb}$ and between $\mathrm{BOD}_{5}$ and COD.

\section{Treatment Measures}

\section{Processing Technology}

Through the analysis of $\mathrm{RCH}$ runoff pollution, the pollutants needed to be dealt with were $\mathrm{BOD}_{5}, \mathrm{SS}, \mathrm{COD}$, petroleum, heavy metals, and some organic matters, etc. SS can be removed by the physical precipitation method. Organic matter generally can be degraded by microbial or other biological methods. It is impossible to use one control measure that has a better effect in treating runoff pollution and can respond to dangerous leaks in the source protection area. In China, stones flaky evaporation pool or steel structure of evaporation pool next to a highway are usually chosen as pavement drainage design, not for collecting all the subgrade water. For a highway crossing a water body that serves drinking and farming finctions, it needs to consider collecting all roadbed drainage. However, there are no design specifications available in China about the valuing of the initial rainwater and treatment process. Therefore, in this paper, according to 
Table 6. Runoff water quality of RCH.

\begin{tabular}{|c|c|c|}
\hline $\begin{array}{c}\text { Monitoring } \\
\text { indicators }\end{array}$ & $\begin{array}{c}\text { Concentrations range } \\
\text { during runoff }(\mathrm{mg} / \mathrm{L})\end{array}$ & EMC $(\mathrm{mg} / \mathrm{L})$ \\
\hline $\mathrm{pH}$ & $6.8 \sim 7.5$ & 7.1 \\
\hline $\mathrm{SS}$ & $157 \sim 227$ & 191 \\
\hline $\mathrm{COD}$ & $155 \sim 231$ & 192 \\
\hline $\mathrm{BOD}_{5}$ & $35.4 \sim 41.4$ & 37.4 \\
\hline $\mathrm{Pb}$ & $0.027 \sim 0.059$ & 0.04 \\
\hline $\mathrm{Zn}$ & $0.047 \sim 0.092$ & 0.07 \\
\hline $\mathrm{NH3}-\mathrm{N}$ & $0.141 \sim 0.292$ & 0.22 \\
\hline $\mathrm{TP}$ & $0.017 \sim 0.033$ & 0.02 \\
\hline petroleum & $0.007 \sim 0.008$ & 0.08 \\
\hline $\mathrm{TN}$ & $0.462 \sim 0.665$ & 0.56 \\
\hline
\end{tabular}

$\mathrm{RCH}$ runoff pollution characteristics and the advantages and disadvantages of various control measures, we referred to the European water environmental protection norms, and designed a concentrated drainage treatment system to process the sensitive drainage sections of Maobagou, Liushayan, and Banqiao reservoirs.

As to the road surface rainwater runoff, in fact, we primarily take into consideration the impact of initial rain on water environment. The road surface rainwater runoff has notable characteristics, that the initial rainwater contains more sewage (SS and petroleum are the main pollutants in wastewater), whereas the later rainwater is cleaner than the initial rainwater. To prevent the pollution from initial rainwater from moving to the surface water and groundwater inside the water resource protection area, we need to collect and process the initial rainwater so that most of the runoff pollutants are removed, and then the relatively cleaner late rainwater can be discharged directly to nearby water bodies. The rainwater takes away road surface pollutants in the early stage of rainfall and is classified as initial rainwater, and the initial rainwater can also be divided into two types: one takes away the

Table 7. Correlation of each pollution indicators in $\mathrm{RCH}$.

\begin{tabular}{|c|c|c|}
\hline Index & $\begin{array}{c}\text { The regression } \\
\text { equation }\end{array}$ & $\begin{array}{c}\text { The correlation } \\
\text { coefficient }\end{array}$ \\
\hline $\mathrm{COD}$ and $\mathrm{SS}$ & $\mathrm{y}=0.9701 \mathrm{x}-0.1866$ & 0.9063 \\
\hline $\mathrm{BOD}_{5}$ and $\mathrm{SS}$ & $\mathrm{y}=0.0787 \mathrm{x}+22.688$ & 0.9013 \\
\hline $\mathrm{Pb}$ and $\mathrm{SS}$ & $\mathrm{y}=0.0004 \mathrm{x}-0.0414$ & 0.9021 \\
\hline $\mathrm{NH} 3-\mathrm{N}$ and $\mathrm{SS}$ & $\mathrm{y}=0.0022 \mathrm{x}-0.2054$ & 0.9135 \\
\hline $\mathrm{Zn}$ and $\mathrm{SS}$ & $\mathrm{y}=0.0005 \mathrm{x}-0.0425$ & 0.8158 \\
\hline $\mathrm{TP}$ and $\mathrm{SS}$ & $\mathrm{y}=0.0002 \mathrm{x}-0.0199$ & 0.8468 \\
\hline $\mathrm{Pb}$ and $\mathrm{Zn}$ & $\mathrm{y}=1.3404 \mathrm{x}+0.0091$ & 0.9692 \\
\hline $\mathrm{BOD}_{5}$ and $\mathrm{COD}$ & $\mathrm{y}=0.0770 \mathrm{x}+23.472$ & 0.9311 \\
\hline
\end{tabular}

soluble pollutants and small particles, the other one washes away insoluble and hard movable pollutants. According to both the Europe design standard (8 16 $\mathrm{mm}$ rainfall are categorized as initial rainwater) and the statistical data from the Australian environmental protection department (the grease can be washed clean once rainfall greater than $15 \mathrm{~mm}$ is on the road surface), the $10 \mathrm{~mm}$ of rainfall are considered as initial rainfall. The international treatment method to process initial rainwater includes: sedimentation, filtration, and discharging into the sewage pipe net. There is no sewage pipe net at the project site, so the design employs the sedimentation and filtration treatment technique to process initial rainwater. The process flow of the current design is shown as below (Fig. 2):

influent $\rightarrow$ grid $\rightarrow$ distributing well $\rightarrow$ sedimentation tank (precipitation), or emergency pond $\rightarrow$ constructed wetland (grease traps, filtration, plant uptake) $\rightarrow$ evaporation pond

$$
\begin{gathered}
q=\frac{2022(1+0.674 \lg P)}{(t+9.58 P 0.044)^{0.733}} \\
Q=q \times S \times n
\end{gathered}
$$

...where $q$ is rainfall intensity $\left(\mathrm{L} / \mathrm{s} \bullet \mathrm{hm}^{2}\right), P$ is recurrence period of storm (a), $t$ is rainfall sustained duration ( $\mathrm{min}$ ), $Q$ is bridge deck rainwater runoff $\left(\mathrm{m}^{3} / \mathrm{h}\right), S$ is catchment area $\left(\mathrm{m}^{2}\right)$, and $n$ is the runoff coefficient.

It was calculated about heavy rain intensity in Renhuai that $\mathrm{P}$ is from two years, and $\mathrm{t}$ and $\mathrm{n}$ were 30 minutes and 0.9 , respectively. Therefore, the deck rainwater runoff was calculated according to formula (3). A concentrated drainage treatment device divided distributing between the well, sedimentation tank, constructed wetland, evaporation pond, and emergency pond. Their sizes were $2.0 \mathrm{~m} * 2.0 \mathrm{~m} * 1.5 \mathrm{~m}, 10.0 \mathrm{~m} * 10.0 \mathrm{~m} * 4.0 \mathrm{~m}, 17.84 \mathrm{~m}$ $* 10.0 \mathrm{~m} * 2.0 \mathrm{~m}, 10.0 \mathrm{~m} * 10.0 \mathrm{~m} * 4.0 \mathrm{~m}$ and $5.0 \mathrm{~m} *$ $5.0 \mathrm{~m} * 2.5 \mathrm{~m}$, respectively. According to the designed volume and terrain factors, a concentrated drainage treatment device was set and it can effectively accommodate the rain wash and the washing wastewater. Through the bridge deck drain, runoff on the bridge deck is discharged into the bridge side tube, then into the drain, and ultimately into the concentrated drainage treatment device. A service road from the highway to the evaporation pool was set up to make for easy cleaning and maintenance work in the future.

\section{The Present Situation of Water Environment Monitoring and Treatment Effect}

We sampled and monitored the water in the reservoirs, the influent and effluent of the concentrated drainage treatment system, and $\mathrm{RCH}$ runoff in order to test and verify the treatment effect of the system. The specific sampling sites and pollution indicators are shown in Table 8 . 


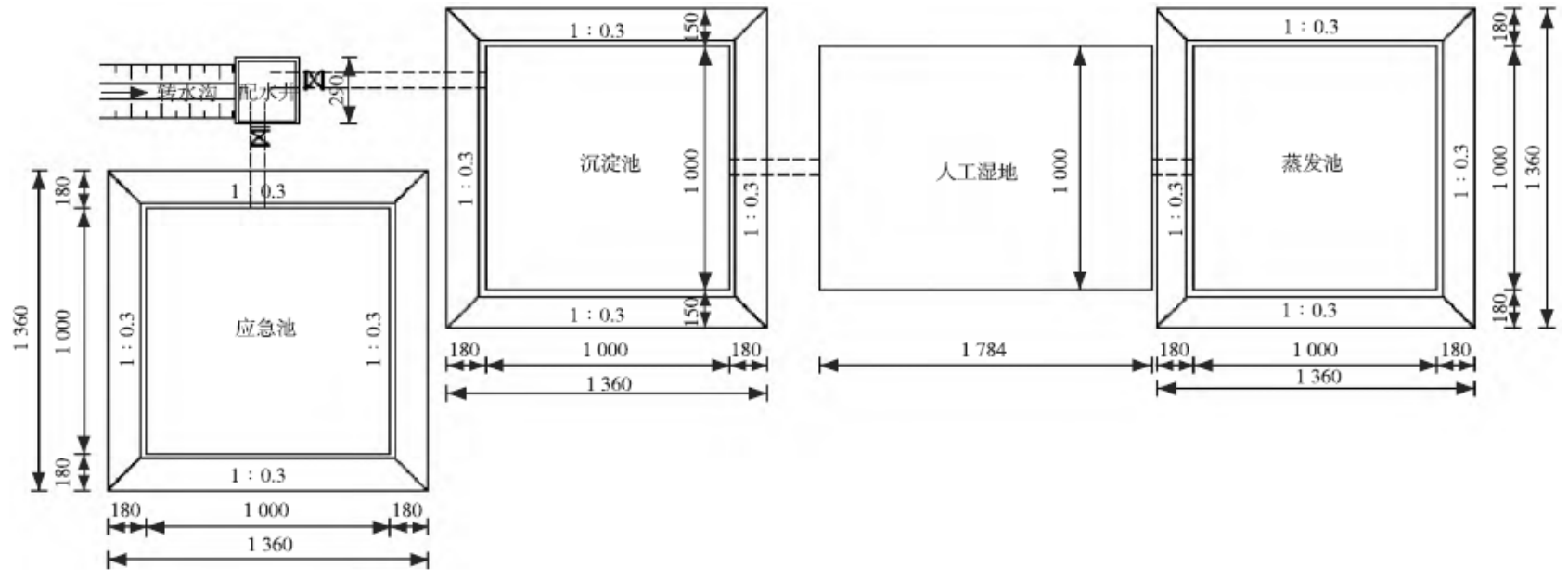

Fig. 2. Flow diagram of a concentrated drainage treatment system.

Table 8. List of water environment monitoring regional situation.

\begin{tabular}{|c|c|c|}
\hline Monitoring area & $\begin{array}{l}\text { Exact location } \\
\text { of the sampling }\end{array}$ & $\begin{array}{c}\text { Monitoring } \\
\text { project }\end{array}$ \\
\hline \multirow{2}{*}{$\begin{array}{c}\text { Concentrated } \\
\text { wastewater treatment } \\
\text { apparatus(ZK14+707) }\end{array}$} & influent & \multirow{6}{*}{$\begin{array}{c}\mathrm{COD}, \mathrm{pH}, \\
\mathrm{BOD}_{5}, \\
\mathrm{NH}_{3}-\mathrm{N}, \\
\text { petroleum, } \\
\mathrm{TP} \text {, heavy } \\
\text { metal, etc. }\end{array}$} \\
\hline & effluent & \\
\hline \multirow{2}{*}{$\begin{array}{c}\text { Concentrated } \\
\text { wastewater treatment } \\
\text { apparatus(ZK15+570) }\end{array}$} & influent & \\
\hline & effluent & \\
\hline \multirow{2}{*}{$\begin{array}{c}\text { Concentrated } \\
\text { wastewater treatment } \\
\text { apparatus }(\mathrm{K} 17+579)\end{array}$} & influent & \\
\hline & effluent & \\
\hline
\end{tabular}

In Table 9, the sampling sites are the same as in Table 2. Compared with monitoring results, $\mathrm{RCH}$ was unfinished in 2013 and the $\mathrm{pH}$ and $\mathrm{Pb}$ concentrations had little change, which conformed with Chinese surface water environment quality standards. The levels of $\mathrm{COD}, \mathrm{BOD}_{5}$, petroleum, and $\mathrm{NH}_{3}-\mathrm{N}$ decreased significantly comparing with the highway construction period, while the concentration of SS increased, and the maximum value was in the range of the surface water environment quality standard (GB38382002), which can be up to standard without processing. From the above experiment monitoring, $\mathrm{RCH}$ construction hasn't impacted drinking water source reserves. Nos. 10-15 were the influent and effluent monitoring indicators

Table 9. Sample point pollution concentrations.

\begin{tabular}{|c|c|c|c|c|c|c|c|c|c|}
\hline $\mathrm{NO}$. & $\begin{array}{c}\mathrm{NH}_{3}-\mathrm{N} \\
(\mathrm{mg} / \mathrm{L})\end{array}$ & $\begin{array}{c}\mathrm{SS} \\
(\mathrm{mg} / \mathrm{L})\end{array}$ & $\mathrm{pH}$ & $\begin{array}{c}\mathrm{COD} \\
(\mathrm{mg} / \mathrm{L})\end{array}$ & $\begin{array}{c}\text { Petroleum } \\
(\mathrm{mg} / \mathrm{L})\end{array}$ & $\begin{array}{c}\mathrm{Pb} \\
(\mathrm{mg} / \mathrm{L})\end{array}$ & $\begin{array}{c}\mathrm{BOD}_{5} \\
(\mathrm{mg} / \mathrm{L})\end{array}$ & $\begin{array}{c}\mathrm{TP} \\
(\mathrm{mg} / \mathrm{L})\end{array}$ & $\begin{array}{c}\mathrm{TN} \\
(\mathrm{mg} / \mathrm{L})\end{array}$ \\
\hline $\mathbf{1}$ & 0.339 & 12.0 & 8.26 & 14.0 & 0.071 & 0.071 & 2.75 & 0.016 & 0.488 \\
\hline 2 & 0.270 & 13.7 & 7.92 & 12.4 & 0.053 & 0.065 & 3.24 & 0.016 & 0.391 \\
\hline 3 & 0.300 & 18.0 & 8.02 & 31.0 & 0.041 & 0.078 & 3.58 & 0.026 & 0.506 \\
\hline 4 & 0.309 & 21.0 & 8.07 & 14.0 & 0.115 & 0.043 & 4.22 & 0.043 & 0.480 \\
\hline 5 & 0.397 & 16.3 & 8.15 & 24.8 & 0.051 & 0.037 & 4.80 & 0.053 & 0.657 \\
\hline 6 & 0.339 & 13.7 & 8.32 & 59.0 & 0.042 & 0.037 & 3.29 & 0.036 & 0.568 \\
\hline 7 & 0.187 & 11.7 & 8.03 & 10.1 & 0.111 & 0.017 & 2.09 & 0.028 & 0.371 \\
\hline 8 & 0.202 & 12.3 & 8.14 & 10.9 & 0.124 & 0.026 & 2.48 & 0.029 & 0.427 \\
\hline 9 & 0.426 & 22.7 & 8.14 & 59.0 & 0.152 & 0.008 & 3.10 & 0.033 & 0.648 \\
\hline 10 & 0.465 & 141.0 & 8.11 & 201.2 & 0.082 & 0.060 & 42.30 & 0.026 & 0.674 \\
\hline 11 & 0.290 & 12.0 & 8.04 & 15.5 & 0.021 & 0.023 & 4.17 & 0.023 & 0.409 \\
\hline 12 & 0.431 & 173.2 & 7.97 & 173.7 & 0.091 & 0.063 & 31.87 & 0.031 & 0.613 \\
\hline 13 & 0.114 & 12.5 & 8.17 & 19.5 & 0.024 & 0.028 & 2.47 & 0.026 & 0.276 \\
\hline 14 & 0.504 & 205.7 & 8.29 & 202.6 & 0.067 & 0.050 & 34.01 & 0.063 & 0.692 \\
\hline 15 & 0.114 & 18.7 & 8.09 & 34.1 & 0.039 & 0.026 & 2.12 & 0.023 & 0.303 \\
\hline
\end{tabular}


Table 10. The treatment rate of pollution indicators.

\begin{tabular}{|c|c|c|c|c|}
\hline Monitoring area & Pollution indicators & Influent(mg/L) & Effluent(mg/L) & Treatment rate(\%) \\
\hline \multirow{3}{*}{ ZK14+707 } & $\mathrm{SS}$ & 141.0 & 12.0 & 91.49 \\
\cline { 2 - 5 } & $\mathrm{COD}$ & 201.2 & 15.5 & 92.29 \\
\cline { 2 - 5 } & $\mathrm{BOD}_{5}$ & 42.30 & 4.17 & 90.14 \\
\hline \multirow{2}{*}{ ZK15+570 } & $\mathrm{SS}$ & 173.2 & 12.5 & 92.78 \\
\cline { 2 - 5 } & $\mathrm{COD}$ & 173.7 & 19.5 & 92.77 \\
\hline \multirow{2}{*}{$\mathrm{K} 17+579$} & $\mathrm{BOD}$ & 31.87 & 2.47 & 90.91 \\
\cline { 2 - 5 } & $\mathrm{SS}$ & 205.7 & 18.7 & 83.17 \\
\cline { 2 - 5 } & $\mathrm{COD}$ & 34.01 & 34.1 & 93.77 \\
\hline
\end{tabular}

of the concentrated drainage treatment system whose stakes were ZK14+707, ZK15+570 and K17+579, respectively. The sampling sites are shown in Table 8 .

From the monitoring results, $\mathrm{pH}$ and concentrations of $\mathrm{NH}_{3}-\mathrm{N}$ and $\mathrm{Pb}$ in the influent could achieve the primary standard of integrated wastewater discharge standard (GB8978-1996). The concentrations of SS, COD, and $\mathrm{BOD}_{5}$ in the influent exceeded the standard. The processing rates of the concentrated drainage treatment device are shown in Table 10. Some indexes of the water from the centralized drainage water treatment device were sampled, monitored, and analyzed, and the results showed its treatment rate at over $83.17 \%$, and the effluents of concentrated drainage treatment device achieved the primary integrated wastewater discharge standard (GB8978-1996). In other words, the effluents can meet the demands of the integrated wastewater discharge standard (GB8978-1996) in China. The results showed that the road line selection had been right and the design had been reasonable. The results could provide decision support for sustainable use of water resources and the harmonious development between man and nature and other targets.

\section{Conclusions}

We haven't yet had a good mature process for the drainage of the drinking water source reserves. In regards to previous similar highway problems, either the conventional processing technology, whose treatment effect is poorer, or avoiding the route was employed. A concentrated drainage treatment system was designed in this paper to process the drainage of sensitive sections. We determined the runoff pollution characteristics of $\mathrm{RCH}$ by monitoring runoff data and analyzing the water quality characteristics, the correlation of all pollutants, the contaminant biodegradability, and the emission regularity of RCH runoff. Based on the characteristics of runoff and water source conservation areas, we developed a kind of concentrated drainage treatment system that could process road rainwater runoff, but also deal with unexpected water pollution accidents. The harmful substances that were leaked when an emergency occurs can be intercepted by settling a basin and emergency pool. It left enough buffer time to deal with incidents to ensure the water quality of the water source protection zones. The research result has been officially put into use along the RCH. This study provided the technical support for engineering the practice of highway runoff pollution remediation. It is of scientific significance for exploration into new technologies and methods.

\section{Acknowledgements}

This study was supported by the National Natural Science Foundation of China (Nos. 41273104, 41372259 and 41302207), the Program of Introducing Talents of Discipline to University ("111" Project, Nos.B08039), and the Fundamental Research Funds for the Central Universities (Nos. 310829163405 and 2014G1291076).

\section{References}

1. ZHAO J.Q., LIU S., QIU L.P., Chen Y. The characteristic of expressway runoff quality and pollutants discharge rule. China Environmental Science. 21 (5), 445, 2001.

2. ZHANG X., LI H., YANG X. L. Primary analysis on control measures for Nanjing highway runoff pollution. Pollution Prevention Technique. 21 (3), 73, 2008.

3. STOTZ G. Investigations of the properties of the surface water runoff from federal highways in the FRG. Science of the Total Environment. 59, 329, 1987.

4. BARRETT M. E., IRISH L. B., MALINA J. F. Characterization of highway runoff in Austin, Texas, area, Journal of Environmental Engineering. 124 (2), 131, 1998.

5. KAYHANIAN M., SINGH A., SUVERKROPP C., BORROUM S. Impact of annual average daily traffic on highway runoff pollutant concentrations. Journal of Environmental Engineering. 129 (11), 975, 2003.

6. REN W. Study on oxidizing pond treatment of freeway surface runoff. Xi' an Shan Xi province: Chang'an University. 2005. 
7. DENG X.N., ZHANG H., WU X.B. Study on the pollution in expressway pavement run-off and the roadside water quality. The Western Traffic Science. 2, 7, 2007.

8. LI H., ZHANG X., GAO H.Y. Characterization of contaminated runoff on freeway surface. China Environmental Science. 28 (11), 1037, 2008.

9. FU D.F., SHI J.Q., LI H. First flush analysis of heavy metals in expressway stormwater runoff. Journal of Environmental Science. 29 (8), 1672, 2009.

10. XIE J.G., ZHANG X., LI H. Partitioning fraction of organic pollutants in expressway stormwater runoff. China Environmental Science. 29 (8), 1047, 2009.

11. ZHONG P., CHEN J.D., KONG Y.P., LI N. Experimental research on highway runoff pollution treated by artificial wetland. Highway. 3, 165, 2007.

12. MAO Y.J., GONG Q.Q., CHEN Y.C., YANG Z.M. Contamination characteristic of the runoff in Chongqing expressway. Resource and Environment in the Yangtze Basin. 19 (1), 148, 2010.
13. LI J.Q., MAO K., XIANG L.L. Research on runoff pollution load and first flush effect of Jingcheng Highway. China Water \& Wastewater. 26 (18), 59, 2010.

14. LU Z.Y., LI H., KONG Y.P., L. Y. Research on treatment system of runoff pollutions of bridge surface in Jiujiang to Xiaotang section of expressway around Guangzhou City. Highway. 4, 191, 2008.

15. LIU J., WANG Z.M., LI Y.F., ZHANG X.Y. Removal and transformation mechanisms of pollutant in subsurface flow constructed wetland. Environmental Protection Science. 31 (1), 53, 2005.

16. YE Y., XU P.B., ZHAI Y.B., CHEN L. Characterization of highway runoff pollution. Environmental Science \& Technology. 36 (6), 134, 2013.

17. CHEN Y., ZHAO J.Q., ZHANG X.L., SONG C., YAN Q. Seasonal variation characteristics of the traffic road runoff pollution in Xi'an area. Journal of Safety and Environment. 14 (4), 344, 2014.

18. PROTECTION BUREAU. Water and wastewater monitoring method. Beijing: China Environmental Press. 2002. 
